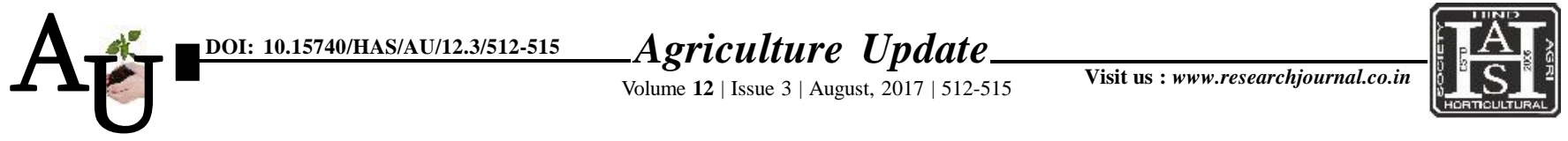

— e ISSN-0976-6847

\title{
Rевявсн поте: The plight of Indian women in agriculture
}

\section{SANDEEP BAINS, RAJDEEP KAUR AND MANISHA SETHI}

Article Chronicle : Received :

07.06.2017;

Accepted :

28.07.2017

\section{Key Words :}

Women, Agriculture, Status, Farming

Author for correspondence :

\section{SANDEEP BAINS}

Department of Apparel and Textile Science,

Punjab Agricultural

University, LUDHIANA

(PUNJAB) INDIA

Email:sandeepct@pau.edu

See end of the article for

authors' affiliations
SUMMARY : The status of women in a society is assessed by the recognition given to their participation and contribution in various fields. When we assess the number of women in farming activities, we realize the impact of the crisis prevailing in the agriculture sector. The seminal role played by our women in the enterprise of agriculture and its related activities has never been documented. Most certainly, our agriculture would not have sustained thus far without the role played by our women in its domain. Women with lower literacy levels and financial income as compared to their male counterparts may be unable to read leaflets or purchase protective equipment, putting their health at risk.

How to cite this article : Bains, Sandeep, Kaur, Rajdeep and Sethi, Manisha (2017). The plight of Indian women in agriculture. Agric. Update, 12(3): 512-515; DOI : 10.15740/HAS/AU/12.3/512-515. 